\title{
空隙構造と化学平衡を考慮した コンクリートの炭酸化反応モデル
}

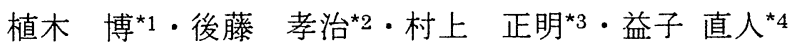

\begin{abstract}
概要 : コンクリートの炭酸化反応に関して, 空隙水中の化学平衡に基づいた $\mathrm{pH}$ を評価指標とするモデルを構築し てきた。今回, 配合, 施工および環境条件から空隙構造をモデル化し, コンクリート中の二酸化炭素の拡散係数 を予測するモデルを新たに組み込んだ。本論文ではこのモデルを用いて炭酸化反応解析を行った結果と, 19 年〜 29 年間供用した鉄筋コンクリート構造物の中性化哚さの実測值とを比較した。その結果, 本解析モデルは既設鉄 筋コンクリート構造物の中性化を概ね予測できることが明らかとなり，鉄筋コンクリート構造物の性能照査や寿 命予測にも適応できる可能性があることを示した。
\end{abstract} キーワード : 炭酸化反応モデル, 空隙構造, $\mathrm{pH}$, 細孔容積分布密度関数, 拡散係数, 化学平衡

\section{1. はじめに}

鉄筋コンクリート構造物の耐久性を論じる場合には, コンクリート中に配置された鋼材の腐食について検討す ることが最も重要である。鋼材はコンクリート中の強ア ルカリ環境下では，その表面に不動態皮膜と呼ばれる酸 化皮膜を形成し，この皮膜が侵入した水分，酸素と鋼材 との反応を遮断して腐食反応の進行を防いでいる。

しかし, 鋼材周辺のコンクリートが中性化し, 空隙水 の $\mathrm{pH}$ が低下するか, あるいは塩化物イオンがある一定 濃度以上存在すると，不動態皮膜は破壊される1)。

このため, 鋼材周辺のコンクリートの $\mathrm{pH}$ を適切に評 価し，腐食開始時期を予測することが，鉄筋コンクリ一 卜構造物の耐久性や維持管理を考える際に不可欠となる。

しかしながら, 硬化コンクリートの $\mathrm{pH}$ を適切に测定 する手法は, 存在しない1のが現状であり, $\mathrm{pH}$ を解析的 に評価できるモデルが必要となる。従来の中性化に関す る研究たとえば 2), 3) は鋼材周辺の空隙水の $\mathrm{pH}$ を直接評価指 標とし,これを予測する手法は皆無であった。このため, 一般環境下にあるこれら構造物の $\mathrm{pH}$ の低下に伴う鋼材 腐食によるかぶりコンクリートのはく離やはく落を予測 することは大変むずかしかった。

一方, 鉄筋コンクリート構造物の設計手法は従来の仕 様規定型から性能照査型に移行しており 4)，鉄筋コンク リート構造物の各種性能に影響を及ぼす劣化要因を明確 にし，その長期性能を定量的に評価できる解析モデルの
構築が求められている。 そこで, 著者らは二酸化炭素の拡散と空隙水中の化学 平衡に基づき $\mathrm{pH}$ を評価指標とした解析モデルを提案し た 5)-9)。この解析モデルでは，コンクリート中の二酸化 炭素の拡散係数がわかれば, 炭酸化反応の進行を予測す ることが可能であり, コンクリート空隙水の $\mathrm{pH}$, 二酸 化炭素, 炭酸化反応生成物の濃度やその経時変化を計算 できる。

コンクリート中の二酸化炭素の拡散係数は，コンクリ 一トの配合, 施工および環境条件により変化する空隙構 造の影響を受けるため, この空隙構造を適切に表現し, 拡散係数を導出できるモデルも必要となる。

本論文では，新たに構造物のコンクリートの配合，施 工および環境条件を考慮した空隙構造モデル等を導入し た総合的な炭酸化反応解析モデルについて詳細を述べた。 さらに，硬化コンクリートの $\mathrm{pH}$ を解析的に推定した結 果と実構造物の中性化深さの測定結果とを比較し, 考察 した。なお,「炭酸化」,「中性化」の用語は文献》の定義 に従った。

\section{2. 化学平衡を考慮したコンクリートの炭酸化 反応モデル}

\section{1 概要}

コンクリートの炭酸化反応は大気中の二酸化炭素（気 体）がコンクリート内部へ拡散する物理過程と，拡散

*1 (財) 首都高速道路技術センター 技術部 (正会員) $\overline{7} 105-0001$ 東京都港区虎ノ門 3-10-11

*2(株) 太平洋コンサルタント 分析事業部 エ博（正会員） テ285-8656 千葉県佐倉市大作 2-4-2

*3 日本電子計算 (株) 科学技術事業部 事業戦略室（正会員） $\bar{T} 135-8388$ 東京都江東区東陽 2-4-24

*4 首都高速道路公団 工務部設計技術課 $\bar{T} 100-8930$ 東京都千代田区霞ヶ関 1-4-1 
した二酸化炭素が水酸化カルシウムなどのアルカリ成 分と反応する化学過程との 2 つに分けられる。

本モデルでは，拡散した二酸化炭素がコンクリート 空隙の微小領域で気相一液相一固相に含まれる各成分 と平衡状態にあると仮定してモデル化を行った。

\section{2 物理的モデル}

本解析モデルでは, コンクリート内の連続する空隙 を大気中の二酸化炭素が, Fick の第 2 法則に従って拡 散し, 空隙水に瞬時にHenry の法則に従って溶解する とした。拡散計算に用いた非定常 1 次元拡散方程式を 式(1)に示す。

$$
\frac{\partial C}{\partial t}=D_{\mathrm{CO}_{2}}{ }^{\prime} \frac{\partial^{2} C}{\partial x^{2}}-\Delta\left[C_{s}\right]
$$

$$
\text { ここで, }
$$

$$
\begin{aligned}
& \text { C ：二酸化炭素濃度 }[\mathrm{mol} / 1] \\
& \mathrm{D}_{\mathrm{CO2}}{ }^{\prime} \text { : コンクリート中の二酸化炭素拡散係数 } \\
& {\left[\mathrm{cm}^{2} / \mathrm{s}\right]} \\
& \mathrm{t} \text { : 時間 }[\mathrm{s}] \\
& \mathrm{x} \text { : コンクリート表面からの距離 }[\mathrm{cm}] \\
& \Delta\left[\mathrm{C}_{\mathrm{s}}\right] \text { : } \Delta \mathrm{t} \text { 時間当たりに拡散した二酸化炭素 } \\
& \text { の溶解量 }[\mathrm{mol} /(\mathrm{l} \cdot \mathrm{s})]
\end{aligned}
$$

本物理モデルにおいては以下のような仮定を設け ている。すなおち，(1)二酸化炭素はコンクリート中の 気相を表面から梁さ方向に 1 次元的に拡散し，液相中 での物質の移動は考えない，(2)コンクリート中の二酸 化炭素の拡散係数は一定とする。すなわち, 水和反応, 炭酸化反応による空隙構造の変化はなく, コンクリー ト中の水量も一定とする，(3)コンクリート表面の二酸 化炭素の濃度は一定とする, という仮定である。

\section{3 化学的モデル}

本解析モデルでは，炭酸化反応が瞬時に進行し平衡 状態に達するとした化学平衡モデルを用いた。したが って炭酸化の進行は拡散速度が律速となる。

化学平衡モデルでは，二酸化炭素と反応する成分を 酸化カルシウム $(\mathrm{CaO})$ とアルカリ成分 $\left(\mathrm{Na}_{2} \mathrm{O}+\mathrm{K}_{2} \mathrm{O}\right)$ とし，水和生成物および末反応の鉱物から溶出するこ れら成分が反応すると考えた。この時微小領域のコン クリートの空隙水中では, 過去の室内基礎実験 10)の結 果より, 空隙中(気相)の二酸化炭素は, 瞬時に反応相(液 相)である空隙水一溶解し，気相と液相で平衡状態が成 立していると考える。また固相の水酸化カルシウムお よび炭酸カルシウムについても同様に, 液相への溶解 速度および固相への析出速度は非常に速く，液相と固 相で平衡状態が常に成立すると仮定した。

コンクリート中の気相一液相一固相における平衡

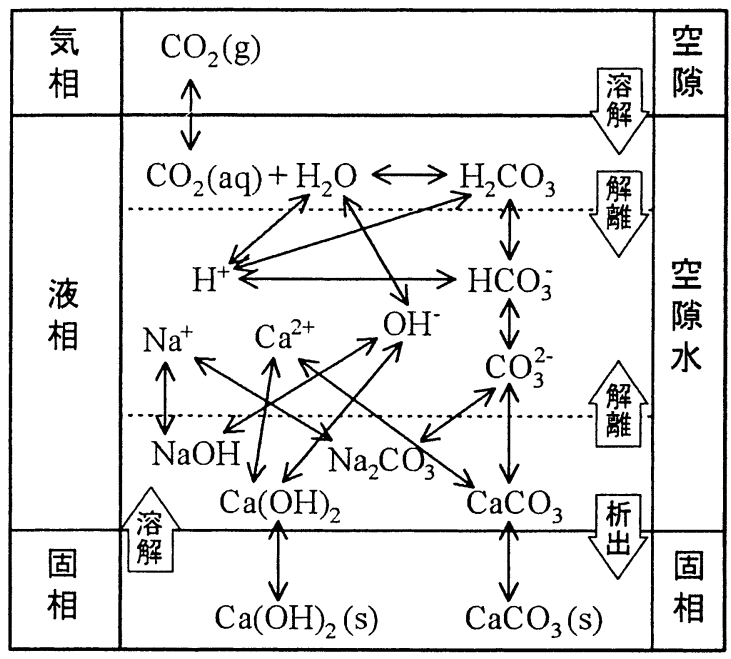

図-1＼cjkstart化学平衡モデルの概念

状態のモデル化の概念をまとめたものが図-1 である。 これらの化学平衡は式(2)から式(10)に示すようにすべ て可逆反応であり，それぞれの成分が相互に平衡状態 を保っている。エーライト,ビーライトの水和によって 生成するケイ酸カルシウム水和物 $(\mathrm{C}-\mathrm{S}-\mathrm{H})$ は溶解度積 が小さい1)ので無視した。なお，本モデルではカリウ ムイオン $\left(\mathrm{K}^{+}\right)$はナトリウムイオン $\left(\mathrm{Na}^{+}\right)$と同じ 挙動をすると仮定した。

式(2)は，気相と液相間の二酸化炭素の溶解平衡であ り, 気相の二酸化炭素は Henry の法則に従って, 空隙 水中に瞬時に溶解するとした。

式(3)は溶解した二酸化炭素の水との反応平衡を示 す。生成した炭酸は, 式(4)と式(5)にしたがって解離し イオンとなる。式(6)～式(9)は溶解度平衡を示し, その 最大值が溶解度積 $K_{S P}$ である。各平衡式においてイオ ン濃度の積が溶解度積を超えた場合は, 各イオンは結 合し固体として析出し，液相から固相一移動する。な お液相中では水酸化カルシウム $\left(\mathrm{Ca}(\mathrm{OH})_{2}\right)$, 炭酸カル シウム $\left(\mathrm{CaCO}_{3}\right)$, 水酸化ナトリウム $(\mathrm{NaOH})$, 炭酸 ナトリウム $\left(\mathrm{Na}_{2} \mathrm{CO}_{3}\right)$ は完全解離しているため, イ オンとしては液相に存在するが, 化学種としては液相 には存在しない。式(10)は, 水の解離平衡式であり $\mathrm{K}_{\mathrm{w}}$ は水のイオン積である。

これらの解離定数, 溶解度から計算できる溶解度積 などは，各種便覧等 11)·13)で与えられている。解析に用 いた平衡定数を表-1に示す。式(2)から式(10)より, 固 相に炭酸カルシウム $\left(\mathrm{CaCO}_{3}(\mathrm{~s})\right)$ あるいは水酸化カル シウム $\left(\mathrm{Ca}(\mathrm{OH})_{2}(\mathrm{~s})\right)$ が存在すれば，気相の二酸化炭 素 $\left(\mathrm{CO}_{2}(\mathrm{~g})\right)$ の濃度に応じた液相の平衡組成が得られ る。気相から液相に溶解した二酸化炭素 $\left(\mathrm{CO}_{2}(\mathrm{aq})\right)$ は, 液相で平衡状態となり, 炭酸イオン濃度が式(7) の溶解度積を上回れば直ちに炭酸カルシウムとして析 出し, カルシウムイオン $\left(\mathrm{Ca}^{2+}\right)$ が減少する。カルシ 
ウムイオンの減少した液相中には, 固相から水酸化力 ルシウムが溶解・解離することにより液相の平衡は保 持される。また，固相の水酸化カルシウムがすべて消 費された後に，さらに気相中へ二酸化炭素が拡散する と, 液相では, 二酸化炭素 $\left(\mathrm{CO}_{2}(\mathrm{aq})\right)$ が増加する。 これに伴い, 水素イオン $\left(\mathrm{H}^{+}\right)$が増加して $\mathrm{pH}$ は低下 すると炭酸水素イオン $\left(\mathrm{HCO}_{3}\right)^{\circ}$ が増加し, 炭酸イオン $\left(\mathrm{CO}_{3}{ }^{2}\right)$ は減少するため, 炭酸カルシウムは, 再溶解 する。このような変化は, 気相の二酸化炭素濃度が大 気中の濃度と等しくなるまで継続する。

このように, 二酸化炭素濃度と液相中のアルカリイ オン濃度が入力されると, 液相中の各種イオンおよび 化学種の濃度は式(2)〜式(10)により計算できる。
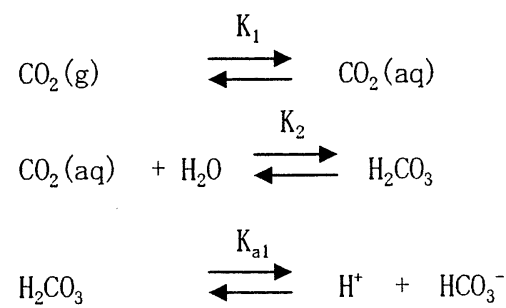

$\mathrm{HCO}_{3}{ }^{-}$

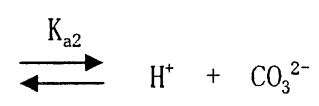

$\mathrm{Ca}(\mathrm{OH})_{2}(\mathrm{~s})$

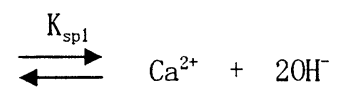

$\mathrm{CaCO}_{3}(\mathrm{~s})$

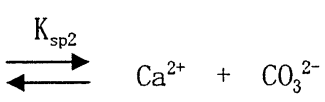

$\mathrm{NaOH}(\mathrm{s})$

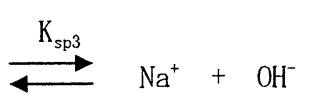

$\mathrm{Na}_{2} \mathrm{CO}_{3}(\mathrm{~s})$

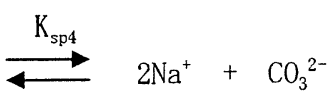

$\mathrm{H}_{2} \mathrm{O}$

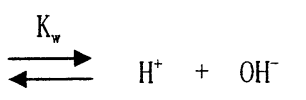

\section{表-1 平衡定数}

\begin{tabular}{|l|ll|}
\hline 式(2) & $\mathrm{K}_{1}=\left[\mathrm{CO}_{2}(\mathrm{aq})\right] /\left[\mathrm{p}_{\mathrm{CO} 2}\right]=1.0 \times 10^{-1.41}$ & $\left(25^{\circ} \mathrm{C}\right)$ \\
式(3) & $\mathrm{K}_{2}=\left[\mathrm{H}_{2} \mathrm{CO}_{3}\right] /\left[\mathrm{CO}_{2}(\mathrm{aq})\right]=1.0 \times 10^{-2.8}$ & $\left(25^{\circ} \mathrm{C}\right)$ \\
式(4) & $\mathrm{K}_{\mathrm{a} 1}=\left[\mathrm{H}^{+}\right]\left[\mathrm{HCO}_{3}^{-}\right] /\left[\mathrm{H}_{2} \mathrm{CO}_{3}\right]=1.0 \times 10^{-3.50}$ & $\left(25^{\circ} \mathrm{C}\right)$ \\
式(5) & $\mathrm{K}_{\mathrm{a} 2}=\left[\mathrm{H}^{+}\right]\left[\mathrm{CO}_{3}{ }^{2-}\right] /\left[\mathrm{HCO}_{3}{ }^{-}\right]=1.0 \times 10^{-10.25}$ & $\left(25^{\circ} \mathrm{C}\right)$ \\
式(6) & $\mathrm{K}_{\mathrm{spl}}=\left[\mathrm{Ca}^{2+}\right]\left[\mathrm{OH}^{-}\right]^{2} \leqq 1.0 \times 10^{-5.26}$ & $\left(25^{\circ} \mathrm{C}\right)$ \\
式(7) & $\mathrm{K}_{\mathrm{sp} 2}=\left[\mathrm{Ca}^{2+}\right]\left[\mathrm{CO}_{3}{ }^{2-}\right] \leqq 1.0 \times 10^{-8.35}$ & $\left(25^{\circ} \mathrm{C}\right)$ \\
式(8) & $\mathrm{K}_{\mathrm{sp} 3}=\left[\mathrm{Na}^{+}\right]\left[\mathrm{OH}^{-}\right] \leqq 1.0 \times 10^{2.23}$ & $\left(20^{\circ} \mathrm{C}\right)$ \\
式(9) & $\mathrm{K}_{\mathrm{sp} 4}=\left[\mathrm{Na}^{+}\right]^{2}\left[\mathrm{CO}_{3}{ }^{2-}\right] \leqq 1.0 \times 10^{1.29}$ & $\left(20^{\circ} \mathrm{C}\right)$ \\
式(10) & $\mathrm{K}_{\mathrm{w}}=\left[\mathrm{H}^{+}\right]\left[\mathrm{OH}^{-}\right]=1.0 \times 10^{-14.00}$ & $\left(25^{\circ} \mathrm{C}\right)$ \\
\hline
\end{tabular}

\section{3. コンクリートの空隙構造のモデル化}

\section{1 組織構造の概要}

コンクリートの組織構造は, 骨材やセメント粒子,

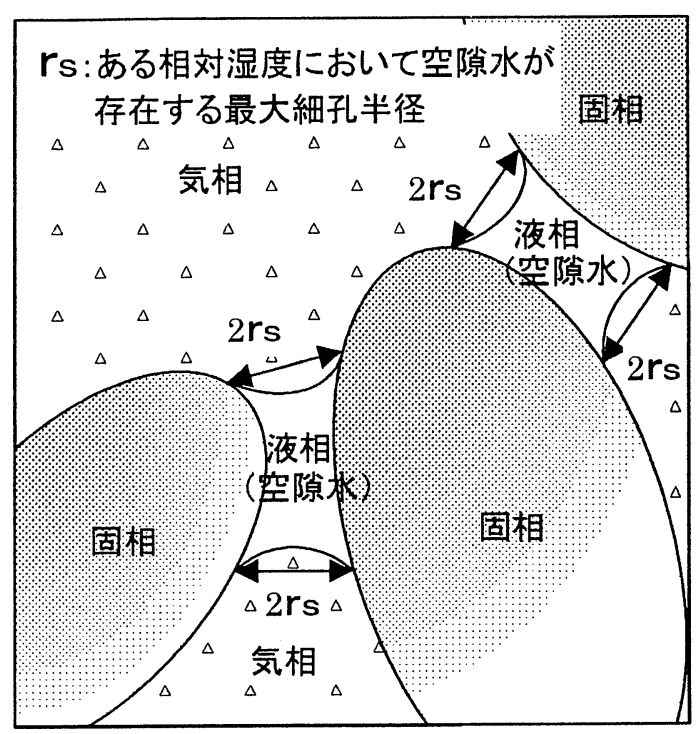

图ー2セメントペーストの組織の模式図

水を含んだ空隙で構成される組織を，水和反応によっ て生成される水和物が徐々に埋めることによって形成 される。したがって,その組織構造は, 配合および施工 の良否と水和反応に影響するセメントの種類や養生条 件を含めた材齢により大きく変化する。セメントの水 和反応の進展により, 組織は微細な空隙（いわゆるゲ ル空隙）を伴って生成するケイ酸カルシウム水和物

（C-S-H）などの水和生成物が, 元々水が存在した 空間に生成するために, コンクリートは多孔質固体と なる。形成されるコンクリートの組織は, 骨材や水和 生成物などの固相とそれ以外の空隙に分けることがで きる。供用中に拀いて水は外気の環境条件によって一 部が蒸発するため, 空隙は水で飽和されたものと水で 飽和されていないものに分けることができる。その状 態を模式的に示したものが図-2である。

2.2 で述べたように，二酸化炭素の移動経路となる のは水で飽和していない連続した空隙と仮定した。し たがって, 空隙構造を適切に表現するモデルが必要で あり，モデルはコンクリートの配合などの初期の組織 を形成する要素と水和反応や炭酸化反応による空隙の 変化を定量的に表現できなければならない。

\section{2 空隙における水分の存在形態}

コンクリートの空隙には, 水蒸気と空気よりなる気 相と空隙水よりなる液相が共存すると考えた。各相が 平衡状態にあるとき, 気液界面が形成される最大細孔 半径を $\mathrm{r}_{\mathrm{s}}[\mathrm{m}]$ とすれば, $\mathrm{r}_{\mathrm{s}}$ より小さい部分は全て空隙 水で満たされることになる。 $\mathrm{r}_{\mathrm{s}}$ は Kelvin の式より(11) 式で表される。

$$
r_{S}=\frac{2 \gamma \cdot M_{W}}{R \cdot T \cdot \rho_{L}}\left(\ln \frac{p_{V}}{p_{V 0}}\right)^{-1}
$$


ここで,

$\gamma \quad$ : 液体の表面張力 $[\mathrm{N} / \mathrm{m}]$

$\mathrm{M}_{\mathrm{w}}$ ：水の分子量 $[\mathrm{kg} / \mathrm{mol}]$

$\mathrm{R}$ : 気体定数 $[\mathrm{J} /(\mathrm{mol} \cdot \mathrm{K})]$

$\mathrm{T}$ ：絶対温度 $[\mathrm{K}]$

$\mathrm{P}_{\mathrm{v}} / \mathrm{P}_{\mathrm{v} 0}$ : 相対湿度 $[-]$

$\rho \mathrm{L} ：$ 空隙水の密度 $\left[\mathrm{kg} / \mathrm{m}^{3}\right]$

気相は二酸化炭素の移動経路となり, 液相は炭酸化 反応の反応場と考えることができる。図-3 はそのしき い值の考え方を模式的に示したものである。 $\mathrm{r}_{\mathrm{s}}$ は湿度 によって変化し，湿度が高くなれば右側に移動し，気 相の容積は減少しコンクリート中の二酸化炭素の拡散 る含水率と拡散係数の関係を明確に示した極めて合理 的なモデル 14) と言える。

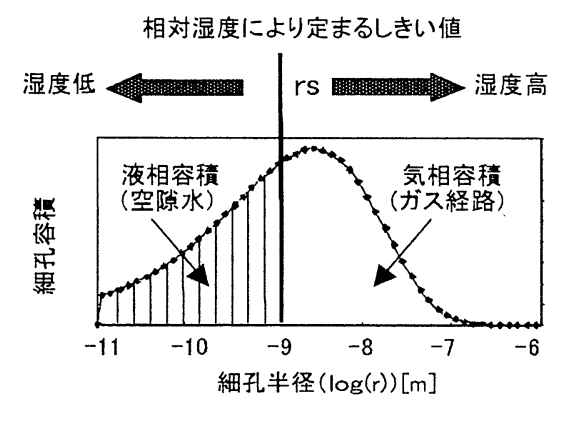

図一3 相対湿度と含水状態の関係 係数は小さくなる。これは一般的な知見より予測され

中に，ある細孔半径を持った空隙がどれだけ存在する かを表わすものであり, 細孔組織の連結や屈曲の状況 など，空間的な構造までを表現するものではない。細 孔容積分布関数を用いる上で以下の仮定を設けた。

すなわち, 細孔組織の全ての空隙部分は, (1)連続し ている，(2)等方性を有している，(3)均質である，とし た。下村によれば式(12)の細孔容積分布密度関数は, コンクリートの配合条件である単位水量, 単位セメン ト量, セメントの種類や鉱物組成に由来するセメント の重量結合水率, 施工条件である乾燥開始材龄により 設定することが可能である。細孔容積分布密度関数を 求めるのに必要な材料定数 $\left.{ }^{15}\right)$ は $\mathrm{V}_{0}, \mathrm{~B}, \mathrm{C}$ の 3 定数 であり，Cを 0.5 とすれば, $V_{0}$ とBは以下の 3 式によ り求めることができる。

$$
\begin{aligned}
& V_{0}=\frac{\underline{W}-\omega \cdot \underline{C}}{\rho_{L}} \\
& \omega=\left(0.061+0.054 \cdot \ln \left(t_{d}\right)\right) \cdot(\underline{W} / \underline{C})^{0.5} \\
& B=\left(1880+2680 \cdot \ln \left(t_{d}\right)\right) \cdot(\underline{W} / \underline{C})^{-1.2} \\
& \text { ここで, } \\
& \underline{\mathrm{W}} \text { ：単位水量 }\left[\mathrm{kg} / \mathrm{m}^{3}\right] \\
& \text { C ：単位セメント量 }\left[\mathrm{kg} / \mathrm{m}^{3}\right] \\
& \omega \text { : セメントの重量結合水率 [一] } \\
& \rho_{\mathrm{L}} \text { ：空隙水の密度 }\left[\mathrm{kg} / \mathrm{m}^{3}\right] \\
& \mathrm{t}_{\mathrm{d}} \text { : 乾燥開始材齢 }[\mathrm{d}]
\end{aligned}
$$

\section{3 空隚構造のモデル化}

炭酸化反応の解析を目的としてコンクリートの空 隙構造をモデル化するには，前節で述べたように二酸 化炭素の移動経路となる気相の空隙と移動経路となら ない液相の空隙とを分けてモデル化することが必要で

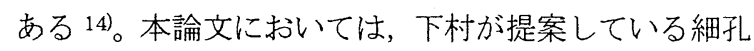
容積分布密度関数 15516)を用いた。

$$
\frac{d V_{(r)}}{d r}=V_{0} \cdot B \cdot C \cdot r^{C-1} \exp \left(-B \cdot r^{C}\right)
$$
ここで,

$\mathrm{r}$ : 細孔半径 $[\mathrm{m}]$

$\mathrm{V}(\mathrm{r})$ ：半径 $\mathrm{r}$ の細孔の容積 $\left[\mathrm{m}^{3} / \mathrm{m}^{3}\right]$

B : 細孔容積分布関数の形状を決めるパラメ 一夕

C ：細孔容積分布関数の形状を決めるパラメ 一タ,ここでは 0.5 とした

$\mathrm{V}_{0}$ ： コンクリート単位体積中における総細孔 容積 $\left[\mathrm{m}^{3} / \mathrm{m}^{3}\right]$

定義した関数は対象とするコンクリート単位体積

\section{4. 解析手法}

\section{1 解析手法の概要}

本モデルで, コンクリートの材料と配合および施工 条件と環境条件から炭酸化反応を予測する。具体的な 解析モデルの考え方を図-4に示す。

入カデータは，セメントの化学組成，コンクリート の単位セメント量と単位水量, 乾燥開始材跉, 供用環 境下の二酸化炭素濃度および湿度である。まずこれら のデータを用い，空隙構造を推定してコンクリート中 の拡散係数を求めた。次に空隙水中のアルカリ濃度お よび反応するカルシウム量を求めた。最後に炭酸カル シウムの生成量, 二酸化炭素の反応量および $\mathrm{pH}$ など の空隙水の各化学種の濃度を求めた。その際, 乾燥開 始材齢以降は, 空隙構造, アルカリ固定量は変化しな いと考えた。解析フローを図-5に，解析に用いたメッ シュ形状を図-6に示す。解析手法として空間方向には 有限要素法を, 時間方向への積分は 2 段階ラックス・ ウエンドロフ法を用いた。解析領域に対する要素分割 は図-6に示す通りで,メッシュ幅は $0.1 \mathrm{~cm}$ とした。 


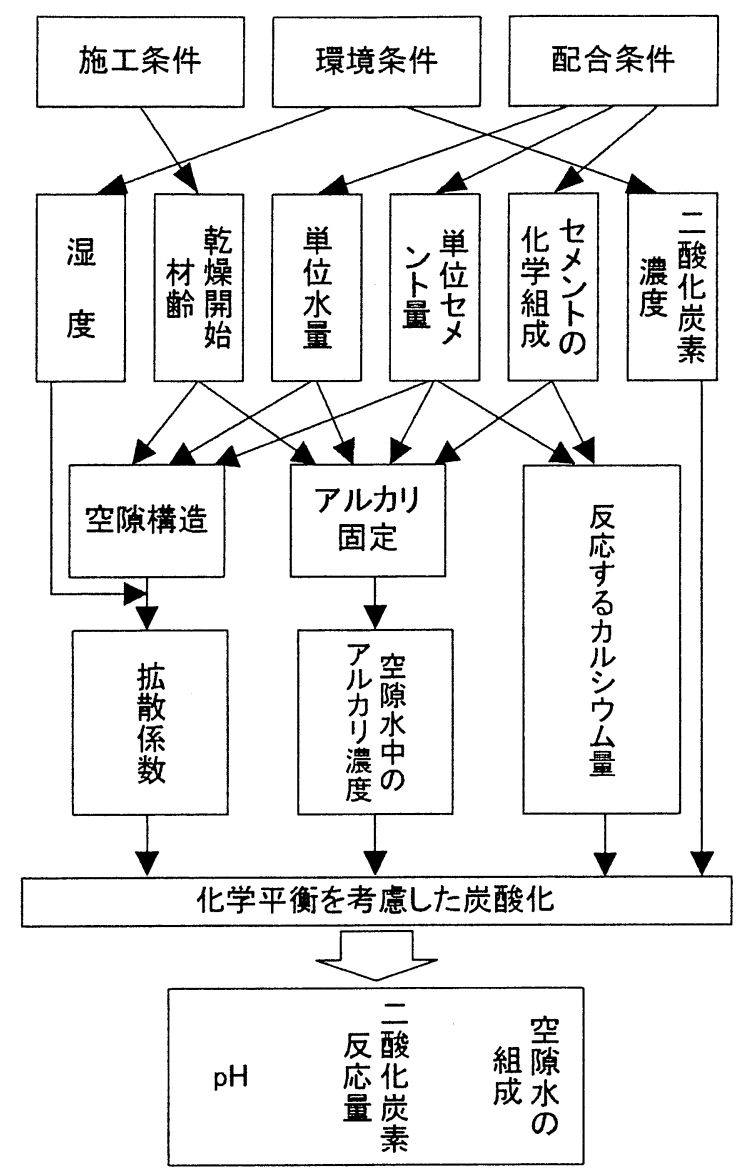

図-4 解析モデルの考え方

二酸化炭素がコンクリート表面（ $\mathrm{x}=0.0 \mathrm{~cm} ）$ から X方 向に 1 次元的に拡散するものとし, 他の境界からの二 酸化炭素の流入出はないとした。解析の時間ステップ は $5.00 \times 10^{5} \sim 1.00 \times 10^{-4}(\mathrm{~d})$ とした。ステップ 1 で炭 酸化反応が始まる前の初期平衡状態を計算する。ステ ップ 2 からステップ 5 を時間ループとして, 各時刻 $\mathrm{t}$ での計算を繰返し行った。ステップ 2 では式(1)の二酸 化炭素の拡散計算を行い, ステップ 3 でコンクリート 表面の二酸化炭素濃度を境界条件として与えた。ステ ップ 4 では, 化学平衡モデル式(2)〜(10)の全ての化学 平衡が成立するまで収束計算を行い, 各時刻 $\mathrm{t}$ での $\mathrm{pH}$ や各化学種の濃度を求めた。

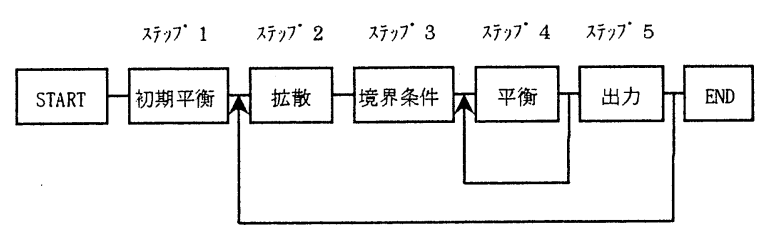

図-5 解析フロー

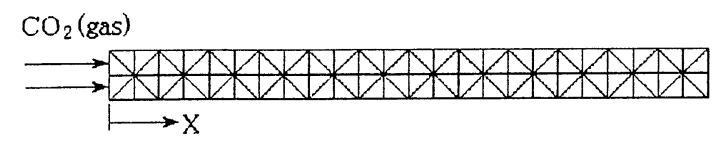

図-6メッシュ形状図 $(\Delta x=0.1 \mathrm{~cm})$

\section{2 コンクリート中の二酸化炭素の拡散係数}

一般に空隙中の気体の拡散係数は, 相互拡散係数を 元に次式で表すことができる ${ }^{17) 。}$

$$
\begin{aligned}
D & =\varepsilon / \tau^{2} \cdot D_{0} \\
\text { ここで, } & \\
D & : \text { 多孔質固体中の気体の拡散係数 }\left[\mathrm{m}^{2} / \mathrm{s}\right] \\
\varepsilon & : \text { 空隙率 }[-] \\
\tau & : \text { 屈曲度 }[-] \\
D_{0} & : \text { 相互拡散係数 }\left[\mathrm{m}^{2} / \mathrm{s}\right]
\end{aligned}
$$

本論文では，下村らが水蒸気の拡散に関して提案し ている式 15)16)を二酸化炭素に応用し，式(17)でコンク リート中の二酸化炭素の拡散係数 DCO2'を表した ${ }^{18)}$ 。

$$
D_{\mathrm{CO}_{2}}{ }^{\prime}=\mathrm{K} \cdot \mathrm{V} \cdot \mathrm{D}_{\mathrm{CO}_{2}}
$$

ここで,

$\mathrm{D}_{\mathrm{CO} 2}$ ：二酸化炭素と空気の相互拡散係数

K : コンクリート細孔組織中の狭さや屈曲 の影響を表わす材料係数で下村の提案し ている式(18) ${ }^{15)}$ を用いる。なお，式 (16) の $1 / \tau^{2}$ と同義と考えることができる。

$$
K=\frac{1}{3} \cdot 120 \cdot B^{-0.69}
$$

V ：二酸化炭素の拡散に有効な空隙率を表 わす材料係数で下村の提案している式 （19）15)を用いた。なお，式（16）の $\varepsilon$ と 同義と考えることができる。

$$
V=V_{0} \cdot \exp \left(B \cdot r_{s}{ }^{c}\right)
$$

これらの係数を用い, コンクリートの配合および乾 燥開始材齢からコンクリート中の二酸化炭素の拡散係 数を求めた。

\section{3 反応するカルシウム量}

炭酸化反応を起こすコンクリート中の対象物質とし て，セメントの水和によって生成する水酸化カルシウ ムのみを想定している例が多いたとえば 14。しかし，セ メントに含まれている酸化カルシウム量のほとんどが 二酸化炭素と反応する 19) ともいわれており，実構造物 のコンクリート中に含まれる炭酸カルシウムの量が全 
カルシウム量の 70\%から 90\%であること 20)から考え ても，水和によって生成した水酸化カルシウムのみが 反応するとは考えられない。一方, 二酸化炭素と水酸 化カルシウムは水分が存在する場合にのみ反応するこ と ${ }^{1}$ から, 環境条件によっては, 水分が不足するため すべてが炭酸化するとも限らない。

本モデルでは反応するコンクリート中の対象物質

(以下反応するカルシウム量）を，セメント中のケイ 酸塩化合物(未反応のエーライト, ビーライトおよび C-S-H) と水酸化カルシウムだけとし, 未反応のアルミ ネート相, フェライト相およびそれらを起源とする水 和物は炭酸化しないと仮定した。反応するカルシウム 量は使用したセメントの化学成分から求めた鉱物組成 とコンクリート配合の単位セメント量から計算するこ とができる。この仮定により, 反応するカルシウム量 は，全カルシウム量の約 $80 \%$ となる。

\section{4 空隚水中のアルカリイオン濃度}

空隙水中に含まれるアルカリは，そのほとんどがセ メントから溶出したものであるが，セメントに含まれ るアルカリ成分（表-4）がすべて空隙水中に存在する わけではない。空隙水中に存在しないアルカリとして は，未反応鉱物中に固溶したまま溶出しないアルカリ と溶出した後に再度固定化したアルカリがあると考え られる。

Taylor ${ }^{21)}$ は空隙水中のアルカリイオン濃度に対して 式(20)を提案している。式(20)はある材柃時のイオン 濃度を表したもので，セメントから放出されるアルカ リ量 $\left(\mathrm{m}_{\mathrm{r}}\right)$ とセメント水和物に固定化（収着）されるア ルカリ量の割合(b)を考虑したものである。材齢の進展 により，水和率が増加するため，セメントから放出さ れるアルカリ量 $\left(\mathrm{m}_{\mathrm{r}}\right)$ は増加し，一方アルカリを収着で きるセメントの水和物(C-S-H と $\mathrm{AFm}$ 相)の割合(P)も また増加するため固定化されるアルカリも増加するこ とを考慮している。本論文では, 空隙水中のアルカリ イオン濃度を求めるのに式(20)を用いることとし, 空 隙水中に存在しないアルカリは, 式(8), 式(9)の化学平 衡には全く関与しないと仮定した。さらに、これら固 定化されているアルカリと炭酸化との関係に関する明 確な知見を持ち合わせていないので，炭酸化によるア ルカリイオン濃度の変化は起こらないと仮定した。

$$
c=m_{r} /(\mathrm{A}+\mathrm{b} \cdot \mathrm{P})
$$

ここで,

c : 空隙水中のイオン種濃度 $[\mathrm{mol} / \mathrm{l}]$

$\mathrm{m}_{\mathrm{r}}$ ：セメントから放出されるアルカリ

$\left(\mathrm{Na}^{+}, \mathrm{K}^{+}\right)$量 $\left[\mathrm{mol} / \mathrm{m}^{3}\right]$

A : 空隙水の体積 $\left[1 / \mathrm{m}^{3}\right]$

b : binding factor $\left[1 / \mathrm{m}^{3}\right]$
$\mathrm{P} \quad: \mathrm{CRP} / \mathrm{CRP}_{\infty} \quad[-]$

$\mathrm{CRP}$ : C-S-H と AFm 相に存在するカルシウム 量 $\left[\mathrm{mol} / \mathrm{m}^{3}\right]$

$\mathrm{CRP}_{\infty}$ ：完全水和後の CRP 值 $\left[\mathrm{mol} / \mathrm{m}^{3}\right]$

\section{5. 解析例による提案手法の検証}

\section{1 既設鉄筋コンクリート壁高欄の現況}

既設鉄筋コンクリート構造物での測定結果と本解析 結果を比較することで本解析モデルを検証する。既設 構造物は, コンクリートのはく離・はく落が顕在化し ており，コアの採取しやすい高速道路上の鉄筋コンク リート壁高欄である。表-2にはこれらのコンクリート の配合条件と供用年数を示す。

なお，ケース $1 ， 3$ の配合は採取したコアを （社）セメント協会 コンクリート専門委員会報告 $\mathrm{F}$ -18「硬化コンクリートの配合推定に関する共同試験 報告」に準拠して配合推定を行った結果であり，ケ一 ス 2 は示方配合の值を用いている。中性化梁さは，コ アを採取し，コア周面にフェノールフタレイン $1 \%$ エ タノール溶液を噴霧し，コア表面から呈色域までの最 小と最大の距離を計測した。平均中性化深さは, フェ ノールフタレインの非呈色域をポリエチレンシートに トレースし,この面積をプラニメータに用いて測定し， コアの周長で除して求めた。

表-2 既設鉄筋コンクリート壁高欄の配合と経過年数

\begin{tabular}{|c|c|c|c|}
\hline 項目 & ケース 1 & ケース 2 & ケース 3 \\
\hline \hline $\begin{array}{c}\text { 単位水量 } \\
\left(\mathrm{kg} / \mathrm{m}^{3}\right)\end{array}$ & 142 & 158 & 167 \\
\hline $\begin{array}{c}\text { 単位セx量 } \\
\left(\mathrm{kg} / \mathrm{m}^{3}\right)\end{array}$ & 349 & 316 & 287 \\
\hline $\begin{array}{c}\text { 水セメント比 } \\
(\%)\end{array}$ & 41 & 50 & 58 \\
\hline セメントの種類 & $\begin{array}{c}\text { 普通ポル } \\
\text { トラント }\end{array}$ & 同左 & 同左 \\
\hline $\begin{array}{c}\text { スランプ } \\
(\mathrm{cm})\end{array}$ & $8 \pm 2.5$ & 同左 & 同左 \\
\hline $\begin{array}{c}\text { 空気量 } \\
(\%)\end{array}$ & $4 \pm 1$ & 同左 & 同左 \\
\hline $\begin{array}{c}\text { 設計基準強度 } \\
\left(\mathrm{kg} / \mathrm{cm}^{2}\right)\end{array}$ & 300 & 同左 & 同左 \\
\hline 供用年数 & 29 & $19,20,21$ & 25 \\
\hline
\end{tabular}

\section{2 解析計算に必要な物性値}

拡散係数を算出するために用いた值を表-3に，仮定 した普通ポルトランドセメントのアルカリ成分および 鉱物組成を表-4に示す。また，アルカリイオン濃度の 算出に用いた各值を表-5に示す。 
表-3 拡散係数の算出に用いた值

\begin{tabular}{|c|c|c|c|c|c|}
\hline 変数 & 定義 & [単位] & $5-x 1$ & $5-x 2$ & $5-23$ \\
\hline$\underline{\mathrm{W}} / \underline{\mathrm{C}}$ & 水セメント比 & [\%] & 41 & 50 & 58 \\
\hline$t_{d}$ & 乾燥開始材令 & [d] & \multicolumn{3}{|c|}{7} \\
\hline $\mathrm{P}_{\mathrm{v}} / \mathrm{P}_{\mathrm{vo}}$ & 相対湿度 & {$[\%]$} & \multicolumn{3}{|c|}{70} \\
\hline$\gamma$ & 液体の表面張力 & {$[\mathrm{N} / \mathrm{m}]$} & \multicolumn{3}{|c|}{0.0727} \\
\hline $\mathrm{M}_{\mathrm{w}}$ & 水の分子量 & {$[\mathrm{kg} / \mathrm{mol}]$} & \multicolumn{3}{|c|}{0.01802} \\
\hline $\mathrm{R}$ & 気体定数 & $\mathrm{J} /(\mathrm{mol} \cdot \mathrm{K})]$ & \multicolumn{3}{|c|}{8.31453} \\
\hline $\mathrm{T}$ & 絶対温度 & {$[\mathrm{K}]$} & \multicolumn{3}{|c|}{293.0} \\
\hline$\rho_{\mathrm{L}}$ & 空隙水の密度 & {$\left[\mathrm{kg} / \mathrm{m}^{3}\right]$} & \multicolumn{3}{|c|}{1000.0} \\
\hline Dco2 & $\begin{array}{l}\text { 二酸化炭素と } \\
\text { 空気の相互拡 } \\
\text { 散係数 }\end{array}$ & {$\left[\mathrm{m}^{2} / \mathrm{s}\right]$} & \multicolumn{3}{|c|}{$0.138 \times 10^{-4}$} \\
\hline$r_{s}$ & 最大細孔半径 & {$[\mathrm{m}]$} & \multicolumn{3}{|c|}{$3.015 \times 10^{-9}$} \\
\hline
\end{tabular}

表-4 セメントの組成（仮定值） [単位：mass\%]

\begin{tabular}{|c|c|c|c|c|c|}
\hline \multicolumn{4}{|c|}{ 鉱物組成 } & \multicolumn{2}{|c|}{ アルカリ成分 } \\
\hline エーライト & ヒ" & 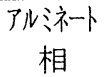 & $\begin{array}{c}\text { フェライト } \\
\text { 相 }\end{array}$ & $\mathrm{Na}_{2} \mathrm{O}$ & $\mathrm{K}_{2} \mathrm{O}$ \\
\hline $\mathrm{C}_{3} \mathrm{~S}$ & $\mathrm{C}_{2} \mathrm{~S}$ & $\mathrm{C}_{3} \mathrm{~A}$ & $\mathrm{C}_{4} \mathrm{AF}$ & & \\
\hline 50.0 & 25.0 & 9.0 & 9.0 & 0.300 & 0.455 \\
\hline
\end{tabular}

表-5 アルカリイオン濃度の算出に用いた值

\begin{tabular}{|c|c|c|c|c|c|c|}
\hline \multirow{2}{*}{} & \multicolumn{2}{|c|}{ ケース 1 } & \multicolumn{2}{c|}{ ケース2 } & \multicolumn{2}{c|}{ ケース 3 } \\
\cline { 2 - 7 } & $\mathrm{Na}_{2} \mathrm{O}$ & $\mathrm{K}_{2} \mathrm{O}$ & $\mathrm{Na}_{2} \mathrm{O}$ & $\mathrm{K}_{2} \mathrm{O}$ & $\mathrm{Na}_{2} \mathrm{O}$ & $\mathrm{K}_{2} \mathrm{O}$ \\
\hline \hline $\mathrm{c}$ & 0.092 & 0.127 & 0.074 & 0.099 & 0.063 & 0.083 \\
\hline $\mathrm{m}_{\mathrm{r}}$ & 12.21 & 14.11 & 11.06 & 12.78 & 10.04 & 11.61 \\
\hline $\mathrm{A}$ & 70.09 & 70.09 & 91.91 & 91.91 & 106.4 & 106.4 \\
\hline $\mathrm{b}$ & 108.2 & 69.80 & 97.96 & 63.20 & 88.97 & 57.40 \\
\hline $\mathrm{P}$ & 0.585 & 0.585 & 0.585 & 0.585 & 0.585 & 0.585 \\
\hline $\mathrm{CRP}$ & 1.616 & 1.616 & 1.463 & 1.463 & 1.329 & 1.329 \\
\hline $\mathrm{CRP}_{\infty}$ & 2.761 & 2.761 & 2.500 & 2.500 & 2.270 & 2.270 \\
\hline
\end{tabular}

計算から得られた二酸化炭素の拡散係数，反応する カルシウム量および空隙水中に存在するアルカリイオ ン濃度, すなわちナトリウムイオン濃度とカリウムイ オン濃度の和を表-6 に示す。また, 環境条件として, 理科年表 11)を参考にして大気中の二酸化炭素濃度を, $0.032 \%$, 相対湿度は東京、横浜の年平均值が $64 \%, 69 \%$ であることから供用期間中 $70 \%$ と仮定した。

表-6 平衡計算に用いた物性値

\begin{tabular}{|l|c|c|c|}
\hline & $\begin{array}{c}\text { 拡散係数 } \\
{\left[\mathrm{m}^{2} / \mathrm{s}\right]}\end{array}$ & $\begin{array}{c}\text { 反応する } \\
\text { カルシウム } \\
\text { 量 }\left[\mathrm{mol} / \mathrm{m}^{3}\right]\end{array}$ & $\begin{array}{c}\text { ア师优 } \\
\text { 濃度 }[\mathrm{mol} / \mathrm{/}]\end{array}$ \\
\hline \hline ケース 1 & $1.96 \times 10^{-8}$ & $3.30 \times 10^{3}$ & 0.438 \\
\hline ケース 2 & $3.38 \times 10^{-8}$ & $2.99 \times 10^{3}$ & 0.346 \\
\hline ケース 3 & $4.78 \times 10^{-8}$ & $2.72 \times 10^{3}$ & 0.292 \\
\hline
\end{tabular}

\section{3 検証と考察}

本モデルを用いて解析した結果として得られるの は，ある経過時間における固相の水酸化カルシウムの
分布, 炭酸カルシウムの分布, さらには空隙水の $\mathrm{pH}$ など式(2)〜(10)に示される各種成分の濃度である。供 用 30 年までの解析結果の例（図-7）は，炭酸化反応に より，時間の経過とともに炭酸化領域がコンクリート 内部一広がって行き, $\mathrm{pH}$ が低下していく様子と，炭 酸化進行領域付近での炭酸カルシウムの増加と水酸化 カルシウムの減少の状況がよく再現されている。得ら れたその他各種成分を示した表-7では，コンクリート 表面付近での $\mathrm{pH}$ は約 10.4 となり,フェノールフタレ インによる測定では発色し，中性化はしていないこと になるが，コンクリートの硬化体中では $\mathrm{pH}$ とフェノ 一ルフタレインの発色との関係は種々の条件によって 変動し，必ずしも一義的に定まらないとも言われてい る 22)。本論では, 解析結果による炭酸化深さを

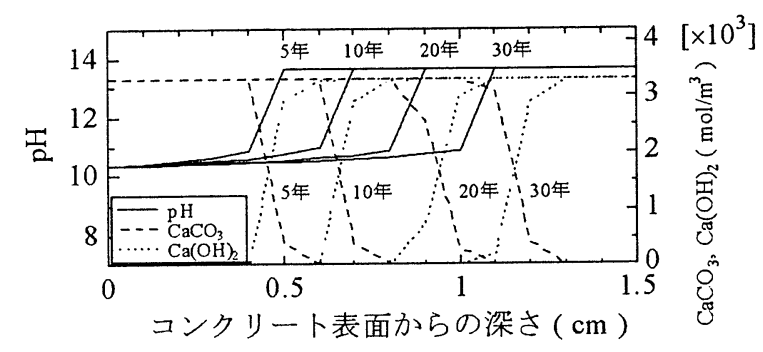

图-7 各時間の pH と炭酸カルシウム生成量（ケース 1)

表-7 各化学種濃度の解析結果 (ケース 1.30 年, 単位 $\mathrm{mol} / \mathrm{l}$ )

\begin{tabular}{|c|c|c|c|}
\hline 深さ & $0.1 \mathrm{~cm}$ & $1.0 \mathrm{~cm}$ & $1.5 \mathrm{~cm}$ \\
\hline \hline $\mathrm{pH}$ & 10.38 & 10.87 & 13.65 \\
\hline $\mathrm{CO}_{2}(\mathrm{~g})$ & $1.18 \times 10^{-5}$ & $1.50 \times 10^{-6}$ & $1.28 \times 10^{-14}$ \\
\hline $\mathrm{CO}_{2}(\mathrm{aq})$ & $1.03 \times 10^{-5}$ & $1.31 \times 10^{-6}$ & $2.35 \times 10^{-18}$ \\
\hline $\mathrm{H}_{2} \mathrm{CO}_{3}$ & $1.63 \times 10^{-8}$ & $2.07 \times 10^{-9}$ & $3.73 \times 10^{-21}$ \\
\hline $\mathrm{HCO}_{3} \cdot$ & $1.22 \times 10^{-1}$ & $4.83 \times 10^{-2}$ & $5.29 \times 10^{-11}$ \\
\hline $\mathrm{CO}_{3}^{2 \cdot}$ & $1.63 \times 10^{-1}$ & $2.00 \times 10^{-1}$ & $1.34 \times 10^{-7}$ \\
\hline $\mathrm{Na}^{+}$ & $4.38 \times 10^{-1}$ & $4.38 \times 10^{-1}$ & $4.38 \times 10^{-1}$ \\
\hline $\mathrm{Ca}^{2+}$ & $2.74 \times 10^{-8}$ & $2.23 \times 10^{-8}$ & $2.76 \times 10^{-5}$ \\
\hline $\mathrm{Ca}(\mathrm{OH})_{2}$ & $\begin{array}{c}0.00 \\
{\left[\mathrm{~mol} / \mathrm{m}^{3}\right]}\end{array}$ & $\begin{array}{c}0.00 \\
{\left[\mathrm{~mol} / \mathrm{m}^{3}\right]}\end{array}$ & $\begin{array}{c}3.30 \times 10^{3} \\
{\left[\mathrm{~mol} / \mathrm{m}^{3}\right]}\end{array}$ \\
\hline $\mathrm{CaCO}_{3}$ & $\begin{array}{c}3.30 \times 10^{3} \\
{\left[\mathrm{~mol} / \mathrm{m}^{3}\right]}\end{array}$ & $\begin{array}{c}3.30 \times 10^{3} \\
{\left[\mathrm{~mol} / \mathrm{m}^{3}\right]}\end{array}$ & $\begin{array}{c}0.00 \\
{\left[\mathrm{~mol} / \mathrm{m}^{3}\right]}\end{array}$ \\
\hline
\end{tabular}

固相の水酸化カルシウムが全て無くなった位置までの 深さとした。すなわち図-7で $\mathrm{pH}$ が大きく低下した位

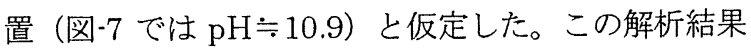
を壁高欄からコアを採取して実測した中性化深さの車 道側と外側の各最大值, 最小值, 平均中性化深さを平 均した值を実測值として土木学会 ${ }^{23)}$ 及び岸谷式 2) と比 較したのが，図-8〜図-10 である。土木学会の予測式 には表・2の水セメント比を用い，環境作用を表す係 数: $\mathrm{R}=1.6$ を用いて算出した。岸谷式では, 水セメ ント比 $60 \%$ 以下の式を用いて, 中性化比率 : $\mathrm{R}=0.4$ として算出した。式(21)に土木学会の予測式, 式(22) に岸谷式を示す。 
[土木学会の予測式 $]$

$$
y=R(-3.57+9.0 W / B) \sqrt{t}
$$

ここで,

$\mathrm{W} / \mathrm{B}$ ：有効水結合材比

$$
=\mathrm{W} /\left(\mathrm{C}_{\mathrm{p}}+\mathrm{k} \cdot \mathrm{Ad}\right)
$$

$\mathrm{W}$ ：単位体積あたりの水の質量

B ：単位体積あたりの有効結合材の質量

$\mathrm{C}_{\mathrm{p}}$ ：単位体積あたりのポルトランドセメント の質量

Ad ： 単位体積あたりの混和材の質量

$\mathrm{R}$ ： 環境の影響を表す係数

$\mathrm{k}$ ： 混和材の影響を表す係数

[岸谷式]

$$
t=\frac{7.2}{R^{2}\left(4.6 x-1.76^{2}\right)} C^{2}
$$

ここで,

$\mathrm{t} \quad$ ： C まで中性化する期間（年）

$\mathrm{x}$ : 強度上の水セメント比

C : 中性化深さ $(\mathrm{cm})$

$\mathrm{R} ：$ 中性化比率

実測した中性化梁さと比較すると水セメント比が低

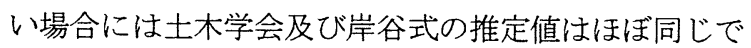
あり，実測值の最小值に近い值を示す。しかし，水セ メント比が少し大きくなると土木学会式は平均値, 岸 谷式㵊小值に近い值と変化していく。

一方, 解析值は平均值よりもむしろ最大值に近く, 水セメント比が大きくなるにつれて，実測值より多少 大きめの值を示すようになるが，ほぼ実測值を安全側 に再現できていることがわかる。なお，壁高欄の設計 上のかぶりは $3.0 \mathrm{~cm}$ であり, 供用 30 年では解析值の 最大は $2.0 \mathrm{~cm}$ 程度で炭酸化は鋼材まで到達しないこと が予測されている。

解析した值と実測值とに差異が認められるので, こ の原因について考察する。本解析で, 炭酸化深さに大 きく影響するのは，拡散係数と反応するカルシウム量 である。

拡散係数については，乾燥開始（7day）以降は供用 期間中一定としており，水和反応や炭酸化反応に伴う 空隙構造の変化を考虑していない。今回, 炭酸化深さ は水セメント比が大きい場合に，実測值より大き目に なった原因は，水和反応の進展に伴う空隙構造の緻密 化を考虑していないために拡散係数を過大評価したこ とであると考えられる。これは今後の課題である。

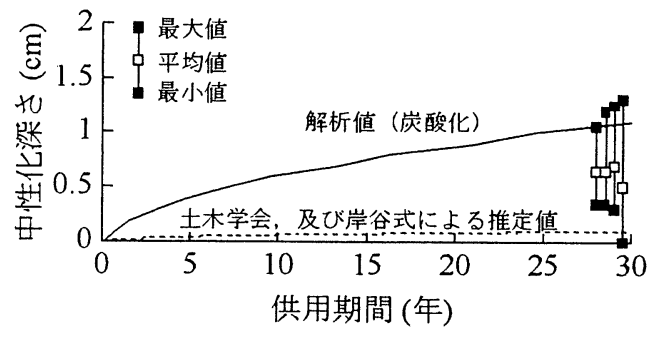

図-8中性化深さの経時的変化（ケース1）

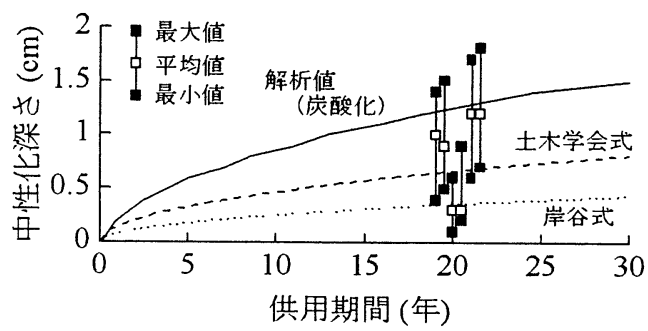

図-9 中性化深さの経時的変化（ケース 2)

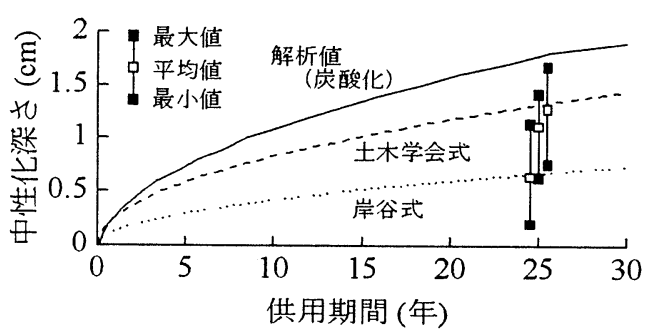

図-10 中性化深さの経時的変化（ケース 3 )

なお，高欄は自動車の排気ガス（NOx，SOx）が作 用しやすい環境にあるため，二酸化炭素と同様にこれ ら物質がコンクリート内部へ拡散し空隙水に溶解し, $\mathrm{pH}$ が低下することも考えられる。この現象に関する 本モデルへの導入は化学平衡モデルに上記の物質の平 衡式を追加することにより求めることができるが，次 回の課題としたい。

\section{6. まとめ}

本研究では，鉄筋コンクリート構造物の中性化現象 に関して, 空隙水の $\mathrm{pH}$ を評価指標とした炭酸化反応 モデルを構築した。本モデルは，二酸化炭素の拡散係 数を配合, 施工および環境条件からコンクリート硬化 体の空隙構造をモデル化することにより求め, かつ空 隙水中のイオン平衡モデルを連成させたことに特色を 有する。

この結果, 過去の多くの研究が二酸化炭素の挔散を 主体に中性化梁さを指標として行われていたのに対し て，炭酸化の程度を $\mathrm{pH}$ により定量的に評価できるだ けでなく各化学種の濃度を評価指標とすることができ 
た。このため，今後は排気ガスの影響なども定量的に 評価することが可能となる極めて汎用性の高い手法と なりうる。

本手法の検証は実構造物の中性化深さで行った。実 構造物では，中性化梁さの実測值はバラツキが大きい が，本解析值は中性化深さを安全側に概ね追跡できる ことが示された。

鋼材の不動態皮膜は $\mathrm{pH}=11$ 付近から破壊され，腐 食が始まる 24)と言われている。本モデルは $\mathrm{pH}$ を評価 手法としていることから，pH の低下に伴う鋼材の腐 食が始まる時期の予測は可能であり，かぶりコンクリ 一トのはく離・はく落防止工事を予防保全として行う 際に有効なツールとなりうる。今後, 実構造物のデー タとの検証を進め, より解析精度の向上を図り, 蓄積 された社会資本を計画的に維持管理するための劣化診 断ツールとして確立していきたいと考えている。

[謝辞］本研究を行うに当り，細孔容積分布密度 関数の導入に関して懇切丁寧なご指導を頂いた 長岡技術科学大学助教授 下村 匠先生に深く感謝申し 上げます。モデル構築には鹿島建設(株）古澤 靖彦氏， (株)エーアンドエーマテリアル 山崎 之典氏よりご助 言を頂きました。また，本論文のまとめには， (株)ワークボックス 河村 隆二氏に御指導, 御支援を 頂きました。記してここに謝意を表します。

[付記］筆者の一人である後藤 孝治氏は平成 14 年 7 月 6 日に逝去されました。

\section{参考文献}

1） 日本コンクリート工学協会：炭酸化研究委員会報告書, p.1, 1993.3

2）岸谷孝一：鉄筋コンクリートの耐久性，鹿岛建設技術研究所出 版部, pp.165, 1963

3）長瀧重義，大賀宏行，佐伯竜彦：コンクリートの中性化深さの 予测，セメント技術年報，№.41，pp.343-346，1987

4) 土木学会, 平成 11 年度版 コンクリート標準示方書一耐久性照 查型一［施工編］pp.9-10，2000.1

5）牧野徹, 植木博, 河村隆二, 山崎之典, 村上正明: 地球化学二 一ドと有限要素法の連成によるコンクリートの炭酸化反応解析， セメントコンクリートの反応モデル解析に関するシンポジウム 論文集, pp.59-64, 1996.5

6）百瀬明貴, 植木博, 山崎之典, 村上正明: コンクリート部材の 炭酸化反応に関するシミュレーション解析, コンクリートエ学 年次論文報告集, Vol.18, No.1, pp.729-734，1996

7）長田光正, 植木博, 山崎之典, 村上正明: アルカリ成分に着目 したコンクリート部材の炭酸化反応シミュレーション解析, コ ンクリート工学年次論文報告集, Vol.19, No.1, pp.793-798, 1997
8）松本洋一, 植木博, 山崎之典, 村上正明: 炭酸カルシウムの再 溶解を考虑した炭酸化反応に関するモデル解析、コンクリート 工学年次論文報告集, Vol.20, No.2, pp.961-966, 1998

9）小西由人, 植木博, 後藤孝治, 川口和広: 空隙水中のイオン平 衡を考虑した炭酸化反応モデル，コンクリート工学年次論文報 告集, Vol.22, No.2, pp.763-768, 2000

10）小西由人, 植木博, 後藤孝治, 石川陽一：コンクリート硬化体 炭酸化モデル構築のための基䃈的実験, コンクリート工学年次 論文報告集，Vol.21，No.2，pp.1087-1092，1999

11）国立天文台編 : 理科年表，平成 13 年，丸善(株)，p.97，2000.11

12）日本化学会編，改訂四版 化学便覧・基礎偏，丸善（株）

13）化学工学会編, 改訂六版 化学工学便覧, 丸善 (株)

14）石田哲也, 前川宏一：物質移動則と化学平衡論に基づく空隙水 の pH 評価モデル, 土木学会論文集, No.648/V-47, pp.203-215, 2000.5

15）下村匠：細孔容積分布密度関数に基づくコンクリートの乾燥収 縮モデル，東京大学学位論文，1993

16）下村匠，前川宏一: 微視的機構に基づくコンクリートの乾燥収 縮モデル，土木学会論文集，No.520/V-28，pp.35-45，1995.8

17) Gordon R.Youngquist: Diffusion and Flow of Gases in Porous Solids, FLOW THROUGH POROUS MEDIA SYMPOSIUM, Vol.62, No.8, pp.52-63, August 1970

18）植木博, 益子直人, 後藤孝治 : コンクリートの気体拡散係数の 定式化，第 24 回日本道路会議，一般論文集（B）, pp.232-233， 2001

19）山崎之典, 船戸巳知雄, 松里広昭: コンクリート橋脚の炭酸化 と組成変化，コンクリートの炭酸化に関するシンポジウム論文 集, pp.15-22, 1993.4

20）植木博, 益子直人, 後藤孝治, 川口和広 : 既存鉄筋コンクリー 卜部材の炭酸化解析とその考察，コンクリート工学年次論文報 告集, Vol.23, No.2, pp.487-492, 2001

21) H.F.W.Taylor: A method for predicting alkali ion concentrations in cement pore solutions, Advances in Cement Research Vol.1, No.1, pp.5-17,October 1987

22）福島敏夫，川瀬清孝，友沢史紀，赤石博：既存 $\mathrm{RC}$ 造建築物の 外・内壁コンクリートの中性化と炭酸化との関連性（仕上材, 含水状況，使用するフェノールフタレイン溶液の影響)，日本建 築学会大会学術講演梗概集 (東北), pp.253-254, 1982.10

23）土木学会, 2001 年制定 コンクリート標準示方書 [維持管理編] pp.81-85, 2001.1

24）セメント・コンクリートの化学とその応用（社）セメント協 会, pp.47-52, 1994

(原稿受理年月日：2001 年 9 月 10 日) 
Modeling of the carbonation reaction based on pore-structures and chemical equilibrium in pore-water

By Hiroshi Ueki, Takaharu Gotou, Masaaki Murakami and Naoto Mashiko

Concrete Research and Technology, Vol.13, No.3, Sep. 2002

Synopsis: In the past, we presented a model of the carbonation reaction of concrete. For that, the chemical equilibrium in the pore-water was measured by its $\mathrm{pH}$. This time, the pore structure was modeled on the mix proportion, the methods of handling and environmental conditions. In this paper, the results of the carbonation analyses are compared, using this model and the measurements of neutralization in existing reinforced concrete structures (in service for 19 to 29 years). Thus, regarding existing reinforced concrete structures, the comparison shows that this analytical model is useful for (1) predicting the progress of neutralization and (2) being adapted for performance certification and service life estimation.

Keywords : carbonation reaction, pore-sîructures, $\mathrm{pH}$, density distribution function, diffusion coefficient, chemical equilibrium. 